\title{
Bloodless (Liver) Surgery? The Anesthetist's View
}

\author{
Jan Hofland ${ }^{a, b}$ C. Pieter Henny ${ }^{a}$ \\ ${ }^{a}$ Departments of Anesthesiology, Academic Medical Center/University of Amsterdam, Amsterdam, and \\ ${ }^{b}$ Erasmus MC Rotterdam, Rotterdam, The Netherlands
}

\section{Key Words}

Surgery $\cdot$ Anesthesia $\cdot$ Blood loss, surgical $\cdot$ Blood coagulation

\begin{abstract}
Background/Aims: An increasing amount of literature concerning blood conservation, restrictive transfusion strategies, pharmacological manipulation of the hemostatic and fibrinolytic systems, minimal invasive surgery, local hemostatic agents and guidelines for blood transfusion, is being published each year. Is 'bloodless (liver) surgery' or rather minimization of perioperative blood loss and transfusion requirement necessary? Methods: To answer this question, we studied key articles and checked cross-references with the support of PubMed and the Cochrane Database of systematic reviews. Results: At present there is still a need to reduce the use of blood. Pre-donation, set of transfusion triggers, (non-)pharmacological approaches to decrease surgical blood loss, hemodilution techniques, peri- and postoperative cell salvage and postoperative re-transfusion can contribute to the success of a bloodless (liver) surgery program. Conclusion: We conclude that a multidisciplinary effort has to be made through the entire chain, from the outpatient clinic through discharge from the hospital, with the utmost exertion of all team members in which surgeons play a key role in the adaptation of a bloodless (liver) surgery program to the specific needs of patients.
\end{abstract}

Copyright $\odot 2007$ S. Karger AG, Basel
(C) 2007 S. Karger AG, Basel

0253-4886/07/0244-0265\$23.50/0

Fax +4161306 1234

E-Mail karger@karger.ch

www.karger.com
Accessible online at: www.karger.com/dsu

\section{Introduction}

An increasing amount of literature concerning blood conservation, restrictive transfusion strategies, pharmacological manipulation of the hemostatic and fibrinolytic systems, minimal invasive surgery, local hemostatic agents and guidelines for blood transfusion, is being published each year. Most of these articles deal with different strategies to reduce blood loss and transfusion requirement in the perioperative period. Recently, a number of national and international societies 'for the advancement of bloodless medicine' have been launched and the number of institutions claiming the performance of bloodless surgery is increasing [1].

Interestingly, most of the literature on the subject of 'bloodless surgery' has been published in anesthetic, transfusion medical, general medical and hemostatic journals. However, a blood conservational program can only be developed through multidisciplinary effort and knowledge, in which the surgeon also plays a key role $[1,2]$.

Is 'bloodless surgery' or rather minimization of perioperative blood loss and transfusion requirement necessary? If the answer is 'yes', what are the possibilities and what is the role of the surgeon?

The aim of this paper is to show that reduction of the use of allogeneic blood and blood products is necessary, to discuss the possibilities to do so and to show the necessity of a multidisciplinary effort with the surgeon as cornerstone and with special attention given to hepatic surgery.

C.P. Henny, MD, $\mathrm{PhD}$

Department of Anesthesiology, Room H1-130

Academic Medical Center/University of Amsterdam

PO Box 22660, NL-1100 DD Amsterdam (The Netherlands)

Tel. +31 20566 9111, Fax +31 20697 9441, E-Mail C.P.Henny@amc.uva.nl 


\section{Do We Have to Reduce the Use of Blood?}

Is blood-borne viral infection still a problem? Due to rigorous donor selection and the development of more sensitive testing methods, the risk of transfusion-acquired viral infection such as HIV, HTLV and hepatitis B and $\mathrm{C}$, have decreased dramatically [3]. On the other hand, new transfusion-transmitted viruses, such as West Nile virus [4], Simian foamy virus [5], and the variant Creutzfeldt-Jakob disease have been detected [6].

Immunomodulation following blood transfusion increases the risk of postoperative infection which may lead to severe morbidity, treatment of which may be quite costly [7-11]. Although not quite clear, allogeneic blood may cause a more rapid recurrence of the primary tumor or the development of metastases after oncological surgery [12-17]. Additional non-infection risks include transfusion-associated graft-versus-host disease and transfusion-related acute lung injury $[10,18,19]$.

Shortage of bank blood is becoming a threat [3]. Because of severe donor selection in combination with a decreased interest in voluntary blood donation, the number of donations is declining. In addition, an ever-increasing number of elderly patients undergoing large surgical interventions cause a greater demand of banked blood [3]. Even now, in some countries, if an operation such as e.g. a liver transplantation is accompanied by excessive blood loss, other elective surgery will have to be postponed or performed elsewhere due to shortage of blood.

Uncontrollable blood loss during liver surgery has always been a feared complication. Carson et al. [20] reported that blood loss and mortality are related: $<500$ vs. $>2,000 \mathrm{ml}$ blood loss was accompanied by a mortality rate of 8 vs. $43 \%$, respectively. These authors also found a relation between preoperative hemoglobin $(\mathrm{Hb})$ level and mortality in patients refusing blood transfusions: $\mathrm{Hb}$ $>6.2 \mathrm{mmol} / \mathrm{l}(10 \mathrm{~g} / \mathrm{dl})$ vs. $<3.7 \mathrm{mmol} / \mathrm{l}(6 \mathrm{~g} / \mathrm{dl})$ was accompanied by a mortality rate of 7 vs. $62 \%$, respectively [20-22].

Reviewing the above, the question 'do we have to reduce the use of blood' may be answered by: 'yes, definitely'. This in turn implies that the subsequent discussion should address the following:

\section{How Can We Reduce the Use of Allogeneic Blood?}

Most bank blood is used in the perioperative period and in the intensive care unit. To diminish the use of allogeneic blood, a multidisciplinary effort has to be made
Table 1. Contribution of selected blood conservation techniques in surgery $[1,2]$

\begin{tabular}{ll}
\hline Option & $\begin{array}{l}\text { Units of } \\
\text { blood }\end{array}$ \\
\hline $\begin{array}{l}\text { Preoperative } \\
\text { Reduced transfusion trigger }\end{array}$ & $1-2$ \\
$\begin{array}{l}\text { Increase preoperative red cell mass } \\
\text { Preoperative autologous donation }\end{array}$ & 2 \\
\hline $\begin{array}{l}\text { Intraoperative } \\
\text { Meticulous hemostasis and operative technique } \\
\text { Acute normovolemic hemodilution }\end{array}$ & $1-2$ \\
Blood salvage & $\geq 1$ \\
\hline $\begin{array}{l}\text { Postoperative } \\
\text { Restricted phlebotomy }\end{array}$ & $\geq 1$ \\
Blood salvage & $1-2$ \\
\hline
\end{tabular}

through the entire chain, from the outpatient clinic through discharge from the hospital. Perioperative blood loss may have a surgical cause or may be due to either congenital or acquired abnormalities of the hemostatic system. To be able to estimate, treat, but especially diminish blood loss, knowledge with respect to hemostasis, blood conservational techniques, treatment of anemia and transfusion triggers is necessary. Pharmacological manipulation of coagulation, systemic as well as localized, is becoming increasingly important and may influence perioperative blood loss positively as well as negatively. Table 1 shows the contribution of selected blood conservation techniques in surgery as described by Shander and co-workers $[1,2]$.

\section{Preoperative Screening}

Preoperatively, at the outpatient clinic the surgeon should evaluate the patient, taking into account the extent of the scheduled surgical intervention, the estimated amount of intraoperative blood loss, the prevalence of bleeding complications and the required $\mathrm{Hb}$ concentration [23]. At this point in time, a strategy should be formed to minimize perioperative blood loss and transfusion requirement [2]. This encompasses knowledge of the coagulation status of the patient, diagnosis and treatment of preoperative anemia [23], and setting a time path for possible perioperative autotransfusion and blood conservational techniques. Multidisciplinary communication between surgeons, anesthetists, hematologists, in- 
tensivists, nurses and blood bankers can adapt a bloodless surgery program to the specific needs of patients $[1$, $2,23]$. Table 2 gives an overview of advances in bloodless surgery.

In hepatic surgery, bleeding not only results from the hepatic veins and inferior vena cava during parenchymal resection but also is greatly increased due to significant coagulopathy induced by steatosis, cirrhosis, etc. [24]. The most frequent hematological abnormalities in patients with liver disease include decreased synthesis of clotting factors and inhibitors, reduced clearance of activated factors, quantitative and qualitative platelet defects, hyperfibrinolysis and accelerated intravascular coagulation [24]. Vitamin K-dependant clotting factors, protein $\mathrm{C}$ and protein $\mathrm{S}$, presence of thrombocytopenia, hypersplenism and portal hypertension are all factors that preoperatively should be optimized.

\section{Hemostasis}

Hemostasis can be theoretically divided into primary hemostasis (platelet adhesion and aggregation) secondary hemostasis (coagulation cascade resulting in fibrin formation) and the fibrinolytic system (causes plasmin to degrade fibrin, necessary to keep the balance between bleeding and thrombosis).

Abnormalities in all three systems exist and may be congenital or acquired from origin. Congenital hemostatic defects are generally known by the patient; if not a specified patient history generally reveals a hemorrhagic diathesis. Acquired defects are frequently related to underlying disease and/or pharmacologically induced. Thus specific questions relating to a bleeding diathesis and medications will reveal hemostatic abnormalities in more than $95 \%$ of the cases. If a defect is suspected, a general coagulation screening (activated partial thromboplastin time [APTT], prothrombin time [PT] and thrombocyte count) can be performed. If the screening is normal in combination with a strong suspicion of a bleeding diathesis, von Willebrand's disease may be present. When the screening is abnormal the patient should consult a hematologist.

In patients using anticoagulants, fibrinolytic or platelet aggregation inhibitors, the reason for their use should be evaluated and a plan must be made as to when to either stop or antagonize them, depending on the reason for prescription. Table 3 shows frequently used anticoagulants, platelet inhibitors and fibrinolytic agents.

A major problem for pre-testing in liver surgery is that neither the cause and the severity of liver disease, nor the basic coagulation tests are useful in the prediction of excessive intraoperative bleeding $[25,26]$. Furthermore, al-
Table 2. Advances in bloodless surgery - possible drugs or techniques

Preoperative optimization

Increasing red blood cell mass:

Use of (i.v.) iron

Recombinant human erythropoietin

Other recombinant drugs to stimulate platelets or various white blood cells:

Recombinant interleukin-11

Recombinant human thrombopoietin

GM-CSF

G-CSF

$\mathrm{M}-\mathrm{CSF}$

Recombinant factor VIIA

Factor VIII

Factor IX

Intraoperative reduction of losses

Modification of surgical technique:

Laparoscopy

Endoscopy

Robotic surgery

Transcatheter surgical techniques

Ultrasonic scalpel

Argon beam coagulator

Surgical packing material

Modification of anesthetic technique:

Epidural anesthesia

Spinal anesthesia

Optimization of monitoring devices to manipulate hemodynamics, blood oxygen levels, actual coagulation

Acute normovolemic hemodilution

Cell saving

Use of artificial oxygen carriers

Pharmacological interventions

Aprotinin

Antifibrinolytics

Desmopressin

Fibrin glues

Strict transfusion triggers

Postoperative optimization

Recycling of drain blood

Strict transfusion triggers

Low threshold for re-intervention in case of postoperative

bleeding

Re-operation

Angiography combined with arterial embolization

though levels of $\mathrm{Hb}$ and fibrin degradation products, as well as a history of previous upper abdominal surgery have been shown to predict a risk for perioperative blood loss, they all lack sensitivity [27]. In the absence of definitive risk factors, it is recommended that centers should assess their practice individually $[24,27]$. 
Table 3. Anticoagulants, platelet inhibitors and fibrinolytics

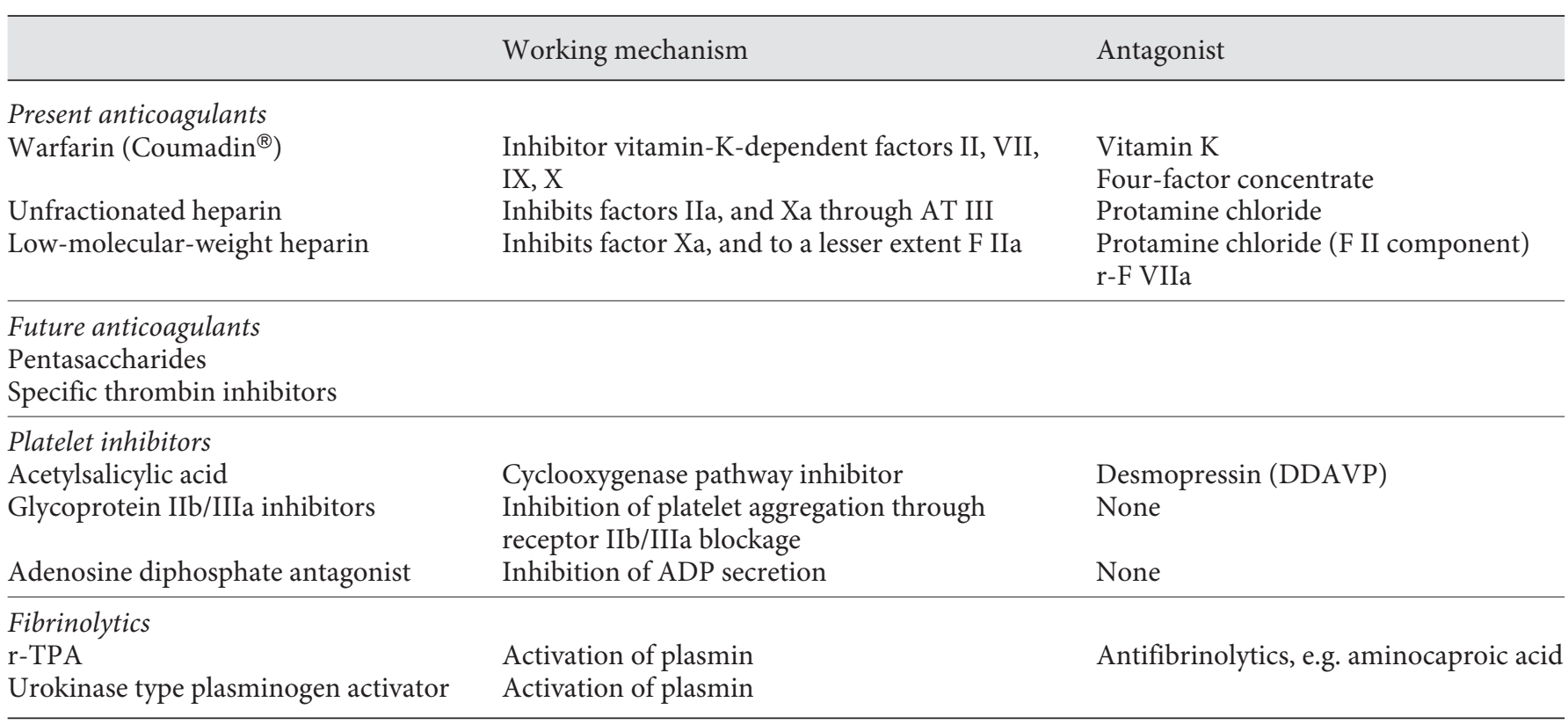

AT III = Antithrombin III; r-F VIIa = recombinant activated factor VII (Novoseven $\left.{ }^{\circledR}\right)$; DDAVP = 1-deamino-8-D-arginine vasopressin; r-TPA = recombinant tissue plasminogen activator.

\section{Anemia}

Depending on the extent of the operation, the estimated blood loss and the co-morbidity of the patient, an impression of the number and function of the erythrocytes may be useful. Generally the $\mathrm{Hb}$ concentration is sufficient. In some groups of ethnic patients, knowledge of the kind and proportion of aberrant $\mathrm{Hb}$ is helpful (e.g. $\mathrm{HbS}$ in sickle cell patients).

Preoperative anemia, usually defined as an $\mathrm{Hb}<8.0$ $\mathrm{mmol} / \mathrm{l}(13 \mathrm{~g} / \mathrm{dl})$, is often encountered. This is frequently seen in the elderly, oncological patients or patients with chronic disease [28], or blood loss [29]. The cause of anemia is easily diagnosed [28]. Perioperative anemia was also found to be an independent risk factor for infection and mortality in surgery [30]. Optimization of the $\mathrm{Hb}$ concentration can be accomplished by iron therapy either orally or intravenously, alone, or in combination with recombinant human erythropoietin (rh-EPO) [31, 32]. Increasing preoperative $\mathrm{Hb}$ will reduce transfusion requirement and may improve postoperative rehabilitation $[1$, 33].

\section{Pre-Donation}

For certain elective interventions, pre-donation of autologous blood (PAD) may be a good option [31, 34]. Ad- ditional treatment with iron and rh-EPO can increase the number of donated units [35]. In a Swiss study, pre-existing anemia with $\mathrm{Hb}<6.8 \mathrm{mmol} / \mathrm{l}(11 \mathrm{~g} / \mathrm{dl})$ proved to be the only contraindication for PAD [36]. Recently it was established that even in esophageal cancer, resection allogeneic blood transfusion worsened the survival of patients in comparison to patients who received transfusion with PAD blood [37].

\section{Intraoperative Phase}

During the preoperative phase a multidisciplinary blood conservational strategy should have been made. Intraoperative blood loss may vary according to type of anesthesia and anesthetic agent used [38, 39]. Elevation of the surgical site by position change may reduce blood loss but at the same time can induce embolism [40]. Maintenance of normal body temperature prohibits deleterious effects of hypothermia on platelet function [41]. Although the different options will be discussed separately, it should be underlined that a combination of techniques is far more effective than one single technique. 


\section{Transfusion Trigger}

The trend in blood management is to restrict transfusion as much as is reasonably possible $[22,42]$. The discussion about this item certainly received a boost by publication of the Transfusion Requirements In Critical Care trial in 1999 [43]. This trial, performed in 838 critically ill patients, documented an overall non-significant trend toward decreased 30-day mortality ( $\mathrm{Hb}$ trigger $<4.3$ $\mathrm{mmol} / \mathrm{l}(7.0 \mathrm{~g} / \mathrm{dl})$ vs. $6.2-7.4 \mathrm{mmol} / \mathrm{l}(10-12 \mathrm{~g} / \mathrm{dl}): 18.7 \mathrm{vs}$. $23.3 \% ; \mathrm{p}=0.11$ ), and a significantly decreased mortality among patients being less acutely ill (APACHE II $\leq 20$ ): (8.7 vs. $16.1 \%: \mathrm{p}=0.03)$ when the restricted approach $(\mathrm{Hb}$ trigger $4.3 \mathrm{mmol} / \mathrm{l}$ ) was followed [43]. Just one year later, the Cochrane Database of Systemic Reviews published its recommendation to become more conservative in common transfusion practice, e.g. to withhold blood transfusion in the presence of $\mathrm{Hb} 4.3 \mathrm{mmol} / \mathrm{l}$ as long as there is no notable bleeding, especially in countries with inadequate screening of donor blood [44].

A successful liver transplant program is known to be highly dependent upon an extensive blood transfusion service with careful planning and organization [45]. Historically, median and maximum intraoperative red blood cell use in orthotopic liver transplant was very high with 28.5 and $251 \mathrm{U}$ respectively for adult patients [46]. However, later reports noted that liver transplantation was possible without the use of blood products when an aggressive preoperative work-up was followed $[47,48]$. With the publication of a multicenter trial studying the effect of aprotinin infusion, a new step was made in the reduction of blood-transfusion requirements [49]. Also the introduction of new surgical techniques like piggyback clamping of the inferior caval vein and comparison of sequential and simultaneous revascularization in adult orthotopic piggyback liver transplantation added some progress in preventing blood transfusion [50]. Several centers are now reporting liver transplantation without any need for blood transfusion in up to $30 \%$ of their patients [51]. Despite these improvements, most patients undergoingliver transplantation still require blood transfusion [51].

\section{Non-Pharmacological Approaches to Decrease \\ Surgical Blood Loss}

Keeping blood loss to a minimum by a non-pharmacological approach can be achieved by influencing the intravascular hydrostatic pressure and by prevention of hemostatic failure [52]. Surgically, techniques such as endoscopy, minimal invasive surgery, and the use of argon beam coagulation, water jet dissectors, microwave tissue coagulation and laser techniques may reduce blood loss [53]. Reduction of systemic arterial and venous hydrostatic pressures is thought to result in lower surgical blood loss, but may be accompanied by an increase in adverse effects [52]. In liver surgery, a very significant correlation was found between blood loss, transfusion requirement and inferior caval vein pressure; $<6,6-12$, and $\geq 13 \mathrm{~mm}$ Hg was accompanied with a mean blood loss of $363,1,259$ and 2,703 $\mathrm{ml}$, respectively [54]. A liberal approach to fluid loading must therefore be prohibited.

Although it requires an experienced anesthesiologist, induced hypotension is a well-known anesthetic technique used to reduce blood loss [52]. Other techniques, such as prevention of hypothermia by aggressive warming [52], and surgical techniques like inflow occlusion of the hepatic artery and portal vein (Pringle's maneuver) [55], and/or total vascular isolation can be used in liver surgery [56].

In a consecutive series of patients undergoing orthotopic liver transplantation that we have studied for comparison of oxygen consumption measurement techniques [57], we found a relationship between blood loss and surgical technique (full cross-clamping vena cava inferior vs. piggyback technique: 11.0 vs. $5.6 \mathrm{l}$, respectively; $\mathrm{p}=0.004$ ) and between blood loss and warm ischemia time (table 4, mean warm ischemia time; $\mathrm{p}=$ $0.007)$. No relationship was found between body temperature and blood loss in these patients (table 4). This latter finding is also in accordance with the literature since the mean body temperature was around $35^{\circ} \mathrm{C}$ and no major impact on blood coagulation is expected at that temperature.

\section{Pharmacological Approaches to Decrease Surgical Blood Loss}

Maintenance of an adequate balance between abnormal bleeding and thrombosis by a careful control of blood coagulation is important in the reduction of blood loss [53]. Although the hemostatic response has classically been described as a cascading series of enzymatic reactions, this model does not satisfactorily explain the dynamic regulation of blood coagulation that occurs in vivo [58]. Functionally, hemostasis can be divided into initiation, propagation, termination and resolution of fibrinolysis [58].

Systemic pharmacological hemostatic agents may be helpful when one has to deal with excessive surgical bleeding, patients with mild hemostatic defects, or in those who refuse blood transfusion [59]. Desmopressin, tranexamic acid, nafamostat, aprotinin and factor VIIa 
Table 4. Data of 20 consecutive patients undergoing orthotopic liver transplantation

\begin{tabular}{|c|c|c|c|}
\hline Mean blood loss $\pm \mathrm{SD}, 1$ & $11.0 \pm 4.1$ & $5.6 \pm 3.6$ & \multirow[t]{2}{*}{0.004} \\
\hline Median blood loss [95\% CI], 1 & $10.0[7.6-14]$ & $4.5[3.3-7.9]$ & \\
\hline Mean temperature pre-anhepatic phase $\pm \mathrm{SD},{ }^{\circ} \mathrm{C}$ & $35.4 \pm 0.5$ & $35.6 \pm 0.9$ & 0.624 \\
\hline Mean temperature anhepatic phase $\pm \mathrm{SD},{ }^{\circ} \mathrm{C}$ & $34.9 \pm 1.0$ & $35.0 \pm 1.1$ & \multirow[t]{2}{*}{0.910} \\
\hline Median temperature anhepatic phase $[95 \% \mathrm{CI}],{ }^{\circ} \mathrm{C}$ & $34.9[34.1-35.8]$ & $35.0[34.3-35.7]$ & \\
\hline Mean temperature post-anhepatic phase $\pm \mathrm{SD},{ }^{\circ} \mathrm{C}$ & $35.1 \pm 0.9$ & $35.2 \pm 1.1$ & \multirow[t]{2}{*}{0.773} \\
\hline Median temperature post-anhepatic phase $[95 \% \mathrm{CI}],{ }^{\circ} \mathrm{C}$ & $34.8[34.3-35.9]$ & $35.0[34.5-35.9]$ & \\
\hline Mean warm ischemia time $\pm \mathrm{SD}, \min$ & $78 \pm 13$ & $58 \pm 23$ & 0.007 \\
\hline \multirow[t]{2}{*}{ Blood loss versus item } & \multicolumn{3}{|c|}{ Spearman rank correlation } \\
\hline & $\mathrm{r}$ & $95 \% \mathrm{CI}$ & $\mathrm{p}$ value \\
\hline Temperature pre-anhepatic phase & -0.39 & -0.72 to 0.07 & 0.088 \\
\hline Temperature anhepatic phase & -0.34 & -0.69 to 0.14 & 0.148 \\
\hline Temperature post-anhepatic phase & -0.44 & -0.75 to 0.03 & 0.060 \\
\hline Warm ischemia time & 0.55 & 0.13 to 0.80 & 0.012 \\
\hline Cold ischemia time & 0.30 & -0.18 to 0.66 & 0.202 \\
\hline
\end{tabular}

95\% $\mathrm{CI}=95 \%$ confidence interval; $\mathrm{SD}=$ standard deviation.

are all used, but are all known to have their advantages and disadvantages [59]. Adequate primary hemostasis is dependent upon the number of blood platelets and their function. If possible, treatment should be guided by laboratory parameters such as platelet count, PT, APTT, INR and fibrinogen level (platelet count $>50,000 / \mathrm{mm}^{3}$, PT and APTT, $<1-1.5$ times reference value, INR $\leq 2.0$, fibrinogen $>1.0 \mathrm{~g} / \mathrm{l})$.

Not only systemic pharmacological hemostatic agents are used to control surgical bleeding, but also topical hemostats and surgical fibrin sealants have a clear role in maintaining hemostasis in liver surgery and transplantation [60]. Quixil ${ }^{\circledR}$, FloSeal ${ }^{\circledR}$, BioGlue ${ }^{\circledR}$, Surgicel Nu$\mathrm{Kit}^{\mathrm{TM}}$, and $\mathrm{TachoSil}{ }^{\circledR}$, all may have their own indication for use [60]. These products may in addition facilitate wound healing and optimize wound integrity in situations where sutures cannot control or may aggravate bleeding [60].

\section{Hemodilution Techniques}

Acute hemodilution can be achieved in two ways [61]. At first by a rapid infusion of fluids without blood withdrawal, called acute hypervolemic hemodilution (AHH). Secondly, by removal of a predetermined amount of whole blood with simultaneous replacement of a combination of colloids and crystalloids to maintain normovolemia: acute normovolemic hemodilution (ANH) [34]. Both techniques essentially reduce the number of erythrocytes lost per volume of blood loss. The advantage of $\mathrm{ANH}$ is that at the end of surgery the patient receives autologous whole blood with viable platelets.

These procedures are performed in the operating room under standard or invasive monitoring conditions depending on patient's co-morbidity and degree of hemodilution [62]. Usually, the systemic hematocrit (Hct) is chosen to describe the degree of hemodilution applied. Moderate hemodilution decreases Hct to $28 \%$ while a reduction to $\leq 20 \%$ is defined as extreme hemodilution 
[63]. Although the exact point at which anemia becomes critical in humans is not known, extremely low Hct levels can be tolerated [64].

The acutely induced anemia is compensated for by a decrease of blood viscosity with a subsequent increase of cardiac output [64]. The improvement of blood flow distribution within the microcirculation enhances tissue perfusion. In addition, a number of vasoactive changes take place in the macro- as well as in the microcirculation ensuring adequate oxygenation of the tissues [65-67].

Although both hemodilution techniques may save blood transfusions, it is unclear whether they influence the total amount of blood loss during surgery [61, 68]. Because AHH will increase vena caval pressure, this technique must be avoided in liver surgery [54].

\section{Cell Salvage}

In short, this technique involves the evacuation of blood from the site of surgery through a suction device, which transports the blood to a cell-saver machine. The cell-saver filters, washes and concentrates the red blood cell suspension to an Hct of $60 \%$. The efficacy of this method very much depends on the surgeon. The suction device should be used as much as possible at the lowest possible pressure. If surgical sponges are used, they should be rinsed and the contents processed [69].

There are two relative contraindications with respect to the use of intraoperative cell salvage (ICS) that are frequently discussed: infected or malignant fields [70]. Processing of blood from an infected surgical site may cause bacteremia or septicemia. Studies indicate that patients with an adequately functioning immune system withstand the bacteremia showing only passing pyrexia. In addition, the routinely used perioperative antibiotics ameliorate the consequences of a transitory bacteremia. A great number of bacteria are eliminated when the blood is passed through a leukocyte-depleting filter after processing [71].

With respect to processing blood from malignant fields, it should be stressed that from a practical point of view, malignant cells can be found in the circulation prior to surgery and many more are driven into the circulation as soon as the surgeon touches the tumor. This occurs both in patients who do not develop metastasis as well as in those who eventually do. Experimental work in the mid-1920s already showed that blood collected through cell salvage contained cancer cells. Later studies, however, indicated that this was not a fact with all types of cancer. More recent work has shown that ICS combined with the use of a modern leukocyte-depletion filter or irradiation (50 Gy) produced a product that was either free of cancer cells or was with cells that were not viable anymore [72]. Recently, two studies were published about ICS with autotransfusion in patients undergoing hepatectomy or liver transplantation for hepatocellular carcinoma [73, 74]. Both studies could not find any modification of the risk of tumor recurrence. Patients receiving autologous blood were found even to have a significantly better survival rate than those receiving homologous blood (cumulative 10year survival rate: 20 vs. $8 \%$, respectively) [73].

In conclusion, ICS can be lifesaving (trauma, acute massive blood loss) and decrease the need to transfuse. With regard to ICS in either infected or malignant fields, the issue is one of balancing risks. On balance the use of antibiotics, leukocyte-depletion filters either alone or in combination with irradiation, can produce a processed product that is as safe, if not safer, than allogeneic blood. ICS in combination with ANH results in a lower transfusion requirement of bank blood than either technique by itself [69].

\section{Postoperative Period}

Any sign of active bleeding during the postoperative phase needs a prompt reaction of the medical team [1]. This makes vigilant monitoring in this phase essential, especially when a bloodless surgery program is followed. Attention should further be paid to the number of phlebotomies performed since often more blood samples are taken than necessary resulting in postoperative anemia $[75,76]$. This may lead to extra transfusions when patients are in their critical $\mathrm{Hb}$ range [75].

Intravenous iron and rh-EPO can further restore acute postoperative anemia [31]. Hct increase was prolonged by 1 week in Jehovah's Witnesses not receiving either intravenous iron or rh-EPO [77]. Optimal nutritional support in this phase is quite important [78].

\section{Postoperative Salvage from Wound Drain Blood}

This salvage can be performed either by means of a mechanical device [79], or through the use of a vacuum system [80]. Interestingly re-infusion of autologous salvaged blood has been found to decrease postoperative infections in orthopedic surgery [81].

\section{Postoperative Re-Transfusion}

In the above-mentioned Swiss study on autologous pre-donation, not only PAD and $\mathrm{ANH}$ were performed, but also additional infusion of salvaged drainage blood postoperatively was applied in $84 \%$ of the patients [36]. 
In doing so, no complications implicating the autotransfusion techniques were encountered and in addition a cost reduction of $40 \%$ compared to homologous blood transfusion was achieved [36].

\section{Conclusion}

It is clear that at present there is still a need to reduce the use of allogeneic blood. A multidisciplinary effort therefore has to be made through the entire chain, from the outpatient clinic through discharge from the hospital, with the utmost exertion of all team members in which surgeons play a key role in the adaptation of a bloodless surgery program. Pre-donation, adherence to transfusion triggers, (non-)pharmacological approaches to decrease intraoperative blood loss, hemodilution techniques, peri- and postoperative cell salvage and postoperative re-transfusion and use of proerythropoietic and/or prohemostatic agents may all contribute to the success of a bloodless (liver) surgery program.

\section{References}

1 Shander A: Surgery without blood. Crit Care Med 2003;31:S708-S714.

$>2$ Goodnough LT, Shander A, Spence R: Bloodless medicine: clinical care without allogeneic blood transfusion. Transfusion 2003;43:668676.

-3 Goodnough LT, Shander A, Brecher ME: Transfusion medicine looking to the future. Lancet 2003;361:161-169.

-4 Pealer LN, Margin AA, Petersen LB, et al: Transmission of West Nile virus through blood transfusion in the United States in 2002. N Engl J Med 2003;349:1236-1245.

5 Centers for Disease Control: Investigations of West Nile virus infections in recipients of blood transfusions. MMWR 2003;51: 1-2 (http://www.cdc.gov/mmwr/preview/ $\mathrm{mmmrhtml/dispatch \_ westnile.htm).}$

-6 Llewelyn CA, Hewitt PE, Knight RSG, et al: Possible transmission of variant CreutzfeldtJakob disease by blood transfusion. Lancet 2004;363:417-421.

-7 Vamvakas EC, Blajchman MA: Deleterious clinical effects of transfusion-associated immunomodulation: Fact or fiction? Blood 2001;97:1180-1195.

8 Agarwal N, Murphy JG, Cayten CG, et al: Blood transfusion increases the risk of infection after trauma. Arch Surg 1993;128:171177.

-9 Pereira A: Deleterious consequences of allogenic blood transfusion on postoperative infection: Really a transfusion-related immunomodulation effect? Blood 2001;98:498500.

10 Blumberg N, Heal JM: Effects of transfusion on immune function. Cancer recurrence and infection. Arch Pathol Lab Med 1994;118: 371-379.

11 Wei AC, Tung-Ping Poon R, Fan S-T, Wong J: Risk factors for perioperative morbidity and mortality after extended hepatectomy for hepatocellular carcinoma. Br J Surg 2003;90: 33-41.

12 Yamamoto J, Kosuge T, Takayama T, et al: Perioperative blood transfusion promotes recurrence of hepatocellular carcinoma after hepatectomy. Surgery 1994;115:303-309.
13 Blumberg N, Agarwal MM, Chuang C: Relation between recurrence of cancer of the colon and blood transfusion. Br Med J (Clin Res Ed) 1985;290:1037-1039.

14 Rosenberg SA, Seipp CA, White DE, et al: Perioperative blood transfusions are associated with increased rates of recurrence and decreased survival in patients with highgrade soft-tissue sarcomas of the extremities. J Clin Oncol 1985;3:698-708.

15 Stephenson KR, Steinberg SM, Hughes KS, et al: Perioperative blood transfusions are associated with decreased time to recurrence and decreased survival after resection of colorectal liver metastases. Ann Surg 1988;208:836843.

16 Kooby DA, Stockman J, Ben-Porat L, et al: Influence of transfusions on perioperative and long-term outcome in patients following hepatic resection for colorectal metastases. Ann Surg 2003;237:860-870.

17 Amato A, Pescatori M: Perioperative blood transfusions for the recurrence of colorectal cancer. The Cochrane Database of Systematic Reviews 2006, Issue 1, Art No CD005033 pub2.

18 Goodnough LT: Risks of blood transfusion. Crit Care Med 2003;31(suppl):S678-S686.

19 Silliman CC, Ambruso DR, Boshkov LK: Transfusion-related cute lung injury. Blood 2005; 105:2266-2273.

20 Carson JL, Poses RM, Spence RK, Bonavita G: Severity of anaemia and operative mortality and morbidity. Lancet 1988;1:727-729.

21 Carson JL: Morbidity risk assessment in the surgically anemic patient. Am J Surg 1995; 170(suppl 6A):S32-S36.

22 Carson JL, Noveck H, Berlin JA, Gould SA: Mortality and morbidity in patients with very low postoperative Hb levels who decline blood transfusion. Transfusion 2002;42:812-818.

23 Goodnough LT, Shander A, Spivak JL, et al: Detection, evaluation, and management of anemia in the elective surgical patient. Anesth Analg 2005;101:1858-1861.
24 Silva MA, Muralidharan V, Mirza DF: The management of coagulopathy and blood loss in liver surgery. Semin Hematol 2004;41 (suppl 1):132-139.

-25 Ritter DM, Rettke SR, Lunn RJ, Bowie EJ, Ilstrup D: Preoperative coagulation screen does not predict intraoperative blood product requirements in orthoptic liver transplantation. Transplant Proc 1989;21:3533-3534.

26 Reverter JC: Abnormal hemostasis tests and bleeding in chronic liver disease: are they related? Yes. J Thromb Haemost 2006;4:717720.

27 Steib A, Freys G, Lehmann C, Meyer C, Mahoudeau G: Intraoperative blood losses and transfusion requirements during adult liver transplantation remain difficult to predict. Can J Anaesth 2001;48:1075-1079.

28 Weiss G, Goodnough LT: Anemia of chronic disease. N Engl J Med 2005;352:1011-1023.

29 Van der Linden P: Perioperative blood conservation strategies: an update for clinicians. Can J Anaesth 2003;50(suppl):S1-S2.

30 Dunne JR, Malone D, Tracy KJ, Gannon C, Napolitano LM: Perioperative anemia: an independent risk factor for infection, mortality, and resource utilization in surgery. J Surg Res 2002;102:237-244.

31 Beris P: The use of iron to increase red cell mass. Can J Anaesth 2003;50(suppl):S3-S9.

32 Goodnough LT: The use of erythropoietin to increase red cell mass. Can J Anaesth 2003; 50(suppl):S10-S18.

33 Carson JL, Terrin ML, Magaziner J: Anemia and postoperative rehabilitation. Can J Anaesth 2003;50(suppl):S60-S64.

- 34 Goodnough LT, Despotis GJ, Merkel K, Monk TG: A randomized trial comparing acute normovolemic hemodilution and preoperative autologous blood donation in total hip arthroplasty. Transfusion 2000;40:1054-1057.

35 Laupacis A, Fergusson D, for the International Study of Perioperative Transfusion (ISPOT) Investigators: Erythropoietin to minimize perioperative blood transfusion: a systematic review of randomised trials. Transfus Med 1998;8:309-317. 
-36 Lagana S, Cattaneo F, Hackenbruch W: Autologous blood transfusion: results with routine use of autologous blood transfusion, normovolaemic haemodilution and postoperative retransfusion of drainage blood salvaged with the Solcotrans system. Swiss Surg 1996;2:244-251.

-37 Takemura M, Osugi H, Higashino M, Takada N, Lee S, Kinoshita H: Effect of substituting allogenic blood transfusion with autologous blood transfusion on outcomes after radical oesophagectomy for cancer. Ann Thorac Cardiovasc Surg 2005; 11:293-300.

-38 Kumarasinghe N, Harpin R, Stewart AW: Blood loss during suction termination of pregnancy with two different anaesthetic techniques. Anaesth Intensive Care 1997;25: 48-50.

-39 Wormald PJ, van Renen G, Perks J, Jones JA, Langton-Hewer CD: The effect of the total intravenous anesthesia compared with inhalational anesthesia on the surgical field during endoscopic sinus surgery. Am J Rhinol 2005 19:514-520.

40 Schneeberger AG, Schulz RF, Ganz R: Blood loss in total hip arthroplasty. Lateral position combined with preservation of the capsule versus supine position combined with capsulectomy. Arch Orthop Trauma Surg 1998;117: 47-49.

-41 Kurz A, Sessler DI, Lenhardt R: Perioperative normothermia to reduce the incidence of surgical-wound infection and shorten hospitalization. Study of Wound Infection and Temperature Group. N Engl J Med 1996;334: 1209-1215.

-42 Carson JL, Ferreira G: Transfusion triggers: How low can we go? Vox Sang 2004;87(suppl 2):S218-S221.

43 Hebert PC, Wells G, Blajchman MA, et al: A multicenter, randomized, controlled clinical trial of transfusion requirements in critical care. Transfusion Requirements In Critical Care investigators. N Engl J Med 1999;340: 409-417.

44 Hill SR, Carless PA, Henry DA, et al: Transfusion thresholds and other strategies for guiding allogeneic red blood cell transfusion (review). Cochrane Database of Systemic Reviews 2000, Issue 1, Art No CD002042.

-45 Carton EG, Rettke SR, Plevak DJ, Geiger HJ, Kranner PW, Coursin DB: Perioperative care of the liver transplant patient. Part 1. Anesth Analg 1994;78:120-133.

-46 Butler P, Israel L, Nusbacher J, Jenkins DE Jr, Starzl TE: Blood transfusion in liver transplantation. Transfusion 1985;25:120-123.

-47 Ramos HC, Todo S, Kang Y, Felekouras E, Doyle HR, Starzl TE: Liver transplantation without the use of blood products. Arch Surg 1994; 129:528-532.

-48 Jabbour N, Gangandeep S, Mateo R, et al: Live donor liver transplantation without blood products: strategies developed for Jehovah's Witnesses offer broad application. Ann Surg $2004 ; 240: 350-357$
49 Porte RJ, Molenaar IQ, Begliomini B, et al: Aprotinin and transfusion requirements in orthotopic liver transplantation: a multicentre randomised double-blind study. EMSALT study group. Lancet 2000;355:1303-1309.

50 Polak WG, Miyamoto S, Nemes BA, et al: Sequential and simultaneous revascularization in adult orthotopic piggyback liver transplantation. Liver Transpl 2005;11:934-940.

51 De Boer MT, Molenaar IQ, Hendriks HG, Slooff MJ, Porte RJ: Minimizing blood loss in liver transplantation: progress through research and evolution of techniques. Dig Surg 2005;22:265-275.

52 Ozier Y, Lentschener C: Non-pharmacologi cal approaches to decrease surgical blood loss Can J Anesth 2003;50(suppl):S19-S25.

53 Gombotz H, Metzler H, List WF: Methods for reduction of perioperative bleeding. Br J Anaesth 1998;81(suppl 1):62-66.

54 Johnson M, Mannar R, Wu AVO: Correlation between blood loss and inferior vena caval pressure during liver resection. Br J Surg 1998;85:188-190.

55 Lodge JP: Hemostasis in liver resection surgery. Semin Hematol 2004;41(suppl 1):7075.

56 Dixon E, Vollmer Jr CM, Bathe OF, Sutherland F: Vascular occlusion to decrease blood loss during hepatic resection. Am J Surg 2005 190:75-86

57 Hofland J, Tenbrinck R, Erdmann W: Comparison of closed-circuit and Fick-derived oxygen consumption during anaesthesia for liver transplantation in patients. Adv Exp Med Biol 2003;540:305-311.

58 Lawson JH, Murphy MP: Challenges for providing effective hemostasis in surgery and trauma. Semin Hematol 2004;41(suppl 1) 55-64.

59 Mahdy AM, Webster NR: Perioperative systemic haemostatic agents. Br J Anaesth 2004 93:842-858

60 Heaton N: Advances and methods in liver surgery: haemostasis. Eur J Gastroenterol Hepatol 2005; 17(suppl 1):S3-S12.

61 Trouwborst A, van Woerkens ECSM, van Daele M, Tenbrinck R: Acute hypervolaemic haemodilution to avoid blood transfusions during major surgery. Lancet 1990;336:12951297.

62 Trouwborst A, van Bommel J, Ince C, Henny CP: Monitoring normovolaemic haemodilution. Br J Anaesth 1998;81(suppl 1):73-78

63 Van Bommel J, Siegemund M, Henny CP, Trouwborst A, Ince C: Critical hematocrit in intestinal tissue oxygenation during severe normovolemic hemodilution. Anesthesiology 2001;94:152-160.

64 Henny CP, Trouwborst A: Physiology of acute vs. chronic anemia. Can J Anesth 2003 50(suppl):S48-S52.

65 Shander A, Rijhwani TS: Acute normovolaemic haemodilution. Transfusion 2004;44 (suppl):S26-S34

66 Bennett J, Haynes S, Torella F, Graigner H McCollum C: Acute normovolaemic haemodilution in moderate blood loss surgery: a randomised controlled trial. Transfusion 2006;46:1097-1103.
67 Van Bommel J, Trouwborst A, Schwarte LA, Siegemund M, Ince C, Henny CP: Intestinal and cerebral oxygenation during severe isovolemic hemodilution and subsequent hyperoxic ventilation in a pig model. Anesthesiology 2002;97:660-670.

68 Van Woerkens ECSM, Trouwborst A, Stijnen T, Schroder FH: A comparative study of different techniques avoiding homologous blood transfusions during major surgical blood loss; in van Woerkens ECSM: Several Aspects of Some Techniques Avoiding Homologous Blood Transfusions, PhD thesis, Rotterdam 1998, pp 75-105.

69 Waters JH: Overview of blood conservation. Transfusion 2004;44(suppl):S1-S3.

70 Waters JH: Indications and contraindications of cell salvage. Transfusion 2004;44 (suppl):S40-S44.

71 Rubens FD, Boodhwani M, Lavalee G, Mesana T: Perioperative red blood cell salvage. Can J Anaesth 2003;50(suppl):S31-S40.

72 Hansen E, Knechel R, Altmeppen J, Taeger $\mathrm{K}$ : Blood irradiation for intraoperative autotransfusion in cancer surgery: demonstration of efficient elimination of contaminating tumor cells. Transfusion 1999;39:608615 .

73 Hirano T, Yamanaka J, Iimuro Y, Fujimoto J: Long-term safety of autotransfusion during hepatectomy for hepatocellular carcinoma. Surg Today 2005;35:1042-1046

74 Muscari F, Suc B, Vigouroux D, et al: Blood salvage autotransfusion during transplantation for hepatic carcinoma: Does it increase the risk of neoplastic recurrence? Transpl Int 2005; 18:1236-1239.

75 Smoller BR, Kruskall MS: Phlebotomy for diagnostic laboratory tests in adults. Pattern of use and effect on transfusion requirements. N Engl J Med 1986;314:1233-1235.

76 Alazia M, Colavolpe JC, Botti G, Corda N, Ramero C, Francois G: Blood loss from diagnostic laboratory tests performed in intensive care units. Preliminary study. Ann Fr Anesth Rèanim 1996;15:1004-1007.

77 Atabek U, Alvarez R, Pello MJ, et al: Erythropoietin accelerates hematocrit recovery in post-surgical anemia. Am Surg 1995;61:7477.

78 Dudrick SJ, O’Donnell JJ, Raleigh DP, Matheny RG, Unkel SP: Rapid restoration of red blood cell mass in severely anemic surgical patients who refuse transfusion. Arch Surg 1985; 120:721-727.

79 Gharehbaghian A, Haque KMG, Truman C, et al: Effect of autologous salvaged blood on postoperative natural killer cell precursor frequency. Lancet 2004;363:1025-1030.

80 Iorwerth A, Wilson C, Topley N, Pallister I: Neutrophil activity in total knee replacement: implications in preventing post-arthroplasty infection. Knee 2003;10:111-113.

81 Peter VK, Radford M, Matthews MG: Retransfusion of autologous blood from wound drains: the means for reducing transfusion requirements in total knee arthroplasty. Knee 2001;8:321-323. 